\title{
BRITISH MUSEUM NATURAL RADIOCARBON MEASUREMENTS VII
}

\section{HAROLD BARKER, RICHARD BURLEIGH, and NIGEL MEEKS}

\author{
Research Laboratory, British Museum, London WC1B 3DG
}

Dates listed below are based on measurements made from June 1968 to May 1970 by the liquid scintillation technique using benzene. In general, the experimental procedure is as described previously (Barker, Burleigh, and Meeks, 1969a) with a few changes in detail. Data are now processed by computer using a comprehensive Algol program written by Andrew Barker, King's College, Univ. of London. There is no need to standardize on any particular sample weight and, as the benzene synthesizer can also deal with samples in the range up to the equivalent of $9 \mathrm{gm}$ of carbon in a single synthesis, the amount of sample available is now less critical. However, for older material, a minimum of $1 \mathrm{gm}$ of carbon is required. Another factor contributing to efficiency of operation is the "bomb" technique for sample combustion (Barker, Burleigh, and Meeks, 1969b), also mentioned in the previous date list. Finally, during 1969, an MS20 double collection mass spectrometer was acquired and all dates (but not all those in this list) are now corrected for isotopic fractionation.

Samples were pretreated for removal of contaminants, with dilute hydrochloric acid and, where appropriate, with dilute alkali also. Bone and antler samples were demineralized in low vacuum with $0.75 \mathrm{~N}$ hydrochloric acid at ambient temperature, leaving only the protein fraction (collagen) which was washed and dried before combustion. Dates were calculated using the Libby half-life for $\mathrm{C}^{14}$ of 5568 years. Descriptions, comments, and references to publications are based on information supplied by the persons who contributed the samples.

\section{ACKNOWLEDGMENT}

Thanks are due to Miss G. I. Hassall, National Physical Laboratory, for isotopic fractionation measurements made in connection with the investigation of $\mathrm{C}^{14}$ age discrepancies using well-dated Egyptian materials.

\section{SAMPLE DESCRIPTIONS \\ ARCHAEOLOGIC SAMPLES

$$
\text { A. Belgium }
$$

\section{BM-372. Moerzeke-Mariekerke figurehead}

Wood (oak) from animal-headed post, probably stem-post from a boat, found ca. 1939, during dredging operations, in the R. Scheldt between Moerzeke and Mariekerke, Belgium ( $51^{\circ} 04^{\prime} \mathrm{N}$ Lat, $4^{\circ} 09^{\prime} \mathrm{E}$ Long). Subm. by R. L. S. Bruce-Mitford from British Mus. colln. Comment: date agrees well with BM-476, below; with which the Moerzeke-Mariekerke head shares some very distinctive stylistic features (Bruce-Mitford, 1967; 1970). Dates show that both heads belong to Migration period. 


\section{BM-476. Appels figurehead}

Wood (oak) from animal-headed post, probably stem-post from a boat, found in 1938 in the R. Scheldt near Appels, Belgium $\left(51^{\circ} 02^{\prime} \mathrm{N}\right.$ Lat, $4^{\circ} 03^{\prime}$ E Long). Subm. by R. L. S. Bruce-Mitford from British Mus. colln. Comment: see BM-372, above. Appels figurehead previously assumed to belong to Viking period; date shows that this figurehead belongs to Migration period (Bruce-Mitford, 1967; 1970).

\section{Flint mine chronology series}

Antler picks from Neolithic flint mines dated for comparison with similar mines in S England (Barker, Burleigh, and Meeks, 1969a), to be pub. elsewhere (Sieveking, ms. in preparation). Only the protein fractions were used for date measurements. Subm. by G. de G. Sieveking, British Mus.

\section{BM-289. Spiennes}

$4230 \pm 130$

Antler pick (ref. 1960, 2.63) from Spiennes, Mons, Prov. of Hainaut, Belgium ( $50^{\circ} 26^{\prime} \mathrm{N}$ Lat, $3^{\circ} 59^{\prime} \mathrm{E}$ Long). Coll. ca. 1855 by D. Tolliez. Sample is from Tolliez colln. now in Ashmolean Mus., Oxford, originally from surface atelier at top of the mine shaft (de Mortillet, 1868). Comment: site is large and mines were evidently in active use for a long period as in the case of Grimes Graves mines, Norfolk, England (Barker and Mackey, 1963). Mining probably began earlier at Spiennes than at Grimes Graves, about same time as at Cissbury area flint mines in $\mathrm{S}$ England (Barker, Burleigh, and Meeks, 1969a).

\section{BM-417. Mesvin}

$5131 \pm 123$

3181 B.c.

Antler pick (ref. 2, P. 1, Base N) from base of Shaft I at $4.2 \mathrm{~m}$ depth at Sans Pareil mine, Mesvin, Mons, Prov. of Hainaut, Belgium $\left(50^{\circ} 24^{\prime}\right.$ 53" N Lat, $3^{\circ} 57^{\prime} 24^{\prime \prime}$ E Long). Coll. 1957 by P. H. Moisin, Soc. Recherche Préhistorique en Hainaut. Comment: date agrees well with measurements of 2 charcoal samples from same mine: Lv-65, $5220 \pm 170$ and Lv-216, $5340 \pm 150$ (Gilot, Ancion, and Capron, 1966).

\section{BM-638. Eglise des Récollets}

$705 \pm 60$

Collagen separated from part of right tibia (ref. Sample C) from human skeleton attributed to Margaret of York from Eglise des Récollets, Mechelen, Belgium (51 ${ }^{\circ} 2^{\prime}$ N Lat, $4^{\circ} 30^{\prime}$ E Long). Coll. 1937 by Winders Max; subm. by F. Twiesselmann, Inst. Royal des Sci. Nat. Belgique. Other samples from bones attributed to Margaret of York dated by Inst. Royal du Patrimoine Artistique (Twiesselmann, 1970, written commun.). Comment: date suggests that it did not belong to skeleton of Margaret of York, who died in A.D. 1503, for which a date ca. 240 yr before 1950 would be expected (see Stuiver and Suess, 1966, fig. 1, p. 538 for relation between radiocarbon ages and true ages for last millennium). 


\section{Egyptian chronology series}

$$
\text { B. Egypt }
$$

The following series consists mainly of samples recently coll. by G. T. Martin, Christ's College, Cambridge, from the Egypt Exploration Society's excavations under W. B. Emery at Sakkara and from the British Mus. colln. Extreme care was taken to ensure secure archaeologic dates, and, where possible, material such as reed or fabric of one or only a few seasons growth, was obtained. Samples were subm. by I. E. S. Edwards, British Mus. This series continues our work on discrepancies between radiocarbon and calendar yr previously reported in 1969, v. 11, p. 281283. Portions of each sample were also measured by Arizona and UCLA labs (Berger, 1970). Wood samples id. by F. R. Richardson, Jodrell Lab., Royal Botanic Gardens, Kew, Surrey (Täckholm and Drar, 1941). Two samples, BM-381 and BM-530, are concerned with general Egyptian chronologic problems and not primarily with $\mathrm{C}^{14}$ discrepancies. Radiocarbon dates for materials historically dated to 2nd and 3rd millennia B.C. generally confirm trend of $\mathrm{C}^{14}$ discrepancies based on measurements of bristlecone pine wood from SW U.S. reported by Suess (1967, 1970), although fine structure of the bristlecone calibration curve is not resolvable with archaeologic material. (For more detail, see Edwards, 1970; Berger, 1970).

\section{BM-317. Mentuhotep II}

$3433 \pm 65$ 1483 B.C.

$\delta C^{13}=-29.0 \%$

Wood (Acacia sp., probably A. nilotica L) from outermost rings of small tree trunk from mortuary temple of Neb-hepet-re-Mentuhotep II (XI Dynasty, ca. 2010 B.c. at Deir el Bahri, Thebes, Egypt (25 $44^{\prime}$ N Lat, 32 $38^{\prime}$ E Long). Coll. 1907 by Egypt Explor. Fund; subm. from British Mus. colln. (E.A. no. 47791). Check on previous gas proportional counter measurement BM-21, $3580 \pm 150$ (Barker and Mackey, 1959). Age based on 5730 yr half-life $3536 \pm 67,1586$ в.c.

\section{Tomb of Wadji}

Four wood samples from tomb (3504) of Wadji (Ist Dynasty, ca. 3025 в.c.) at Sakkara Archaic Cemetery, Egypt $\left(29^{\circ} 51^{\prime} \mathrm{N}\right.$ Lat, $31^{\circ} 14^{\prime}$ E Long). Coll. ca. 1950 by W. B. Emery (1954).

\section{BM-319. Wadji}

Age based on 5730 yr half-life $4352 \pm 72,2402$ в.c. Also dated by GrN-1100, $4360 \pm 60$, 2410 B.C. and GrN-1109, $4460 \pm 55,2510$ B.C. (de Vries and Waterbolk, 1958).

BM-320. Wadji

Age based on 5730 yr half-life $4332 \pm 83,2382$ в.c. 


\section{BM-321. Wadji}

Age based on 5730 yr half-life $4630 \pm 83,2680$ B.c.

BM-322. Wadji

Age based on 5730 yr half-life $4479 \pm 72,2529$ в.c.

\section{BM-323. Hemaka}

Wood (Acacia sp., probably $A$. nilotica L) from mastaba of a nobleman, Hemaka (reign of Udimu, Ist Dynasty, ca. 3000 B.c.) at Sakkara Archaic Cemetery, Egypt (29 $51^{\prime} \mathrm{N}$ Lat, $31^{\circ} 14^{\prime} \mathrm{E}$ Long). Coll. 1937 by W. B. Emery (1938). Check on previous gas proportional counter measurement BM-27, $4100 \pm 150$ (Barker and Mackey, 1959). Sample also dated by P-214, $4447 \pm 150$ (Ralph, 1959). Age based on $5730 \mathrm{yr}$ half-life $4472 \pm 72,2522$ в.c.

\section{Pyramid of Sneferu}

Two wood samples coll. ca. 1950 by Ahmed Fakhry (1959) from S pyramid of Sneferu (IVth Dynasty, ca. 2600 B.c.) at Dahshur, S of Sakkara, Egypt (29 $45^{\prime} \mathrm{N}$ Lat, $31^{\circ} 14^{\prime} \mathrm{E}$ Long).

\section{BM-324. Sneferu}

$3974 \pm 70$

2024 B.C.

$\delta C^{13}=-23.4 \%$

Wood (Juniperus sp., possibly J. phoenicea L) from W passage of S pyramid of Sneferu. Age based on 5730 yr half-life $4093 \pm 72$, 2143 B.c.

\section{BM-325. Sneferu}

$3852 \pm 80$ 1902 B.C.

$$
\delta C^{13}=-26.0 \%
$$

Wood (Cupressus sp., probably C. sempervirens L) from upper chamber of $S$ pyramid of Sneferu. Age based on 5730 yr half-life $3983 \pm 83$, 2033 в.c.

\section{BM-330. Mereruka}

Reed used as bonding between mud-brick courses, $\mathrm{W}$ wall of superstructure, tomb of Mereruka at Sakkara, Egypt (29 $51^{\prime} \mathrm{N}$ Lat, $31^{\circ} 14^{\prime}$ E Long). Mereruka was a great official of Teti, 1st king of VIth Dynasty, ca. 2350 в.C. (Duell, 1938). Coll. 1967 by G. T. Martin (Sample 1/67). Age based on 5730 yr half-life $3880 \pm 118,1930$ B.c. 
BM-331. Teti

$3770 \pm 85$

1820 B.C.

$\delta C^{13}=-22.8 \%$

Wood (Pinus sp., probably $P$. pinea L) from outermost growth rings of large beam $(145 \times 19 \times 19 \mathrm{~cm})$ supporting royal sarcophagus in pyramid of Teti, ca. 2350 B.c., at Sakkara, Egypt $\left(29^{\circ} 51^{\prime} \mathrm{N}\right.$ Lat, $31^{\circ}$ $14^{\prime} \mathrm{E}$ Long). Sarcophagus cannot have been moved since it was placed in position (Leclant, 1966). Coll. 1967 by G. T. Martin (Sample 2/67). Age based on 5730 yr half-life $3880 \pm 88,1930$ в.c.

\title{
BM-332. Cheops boat
}

\author{
$3990 \pm 105$ \\ 2040 B.c. \\ $\delta C^{13}=-16.5 \%$
}

Halfa-grass rope (Nour et al., 1960) from funerary boat of Cheops, $S$ side of Great Pyramid, Giza, Egypt (29 $58^{\prime} \mathrm{N}$ Lat, $31^{\circ} 08^{\prime} \mathrm{E}$ Long). Rope is archaeologically sealed to reign of Cheops, 2nd king of IVth Dynasty, ca. 2600 B.c. Coll. 1967 by Zaky Iskander (Sample 3/67). Age based on 5730 yr half-life $4100 \pm 108,2150$ в.с.

\section{BM-333. Ramasseum}

$$
\begin{aligned}
& 2940 \pm 100 \\
& 990 \text { B.C. } \\
& \delta C^{13}=-14.0 \%
\end{aligned}
$$

Reed used as bonding between mud-brick courses of storage magazine in NW corner of Ramasseum enclosure at Thebes, Egypt $\left(25^{\circ} 41^{\prime}\right.$ $\mathrm{N}$ Lat, $32^{\circ} 40^{\prime} \mathrm{E}$ Long). The Ramasseum (Quibell, 1898) is funerary temple of Ramasses II, XIXth Dynasty, so that sample is sealed to reign of Ramasses II (ca. 1290-1224 B.c.). Coll. 1967 by G. T. Martin (Sample 4/67). Age based on 5730 yr. half-life $3020 \pm 103$, 1070 B.c.

\section{BM-334. Mentuemhat}

$$
\begin{array}{r}
2450 \pm 70 \\
500 \text { B.c. } \\
\delta C^{13}=-12.4 \% \circ
\end{array}
$$

Reed used as bonding between mud-brick courses of $\mathrm{E}$ side of pylon of tomb (No. 34) of Mentuemhat, Fourth Prophet of Amun at Asasif, Thebes, Egypt (25 $41^{\prime} \mathrm{N}$ Lat, $32^{\circ} 40^{\prime} \mathrm{E}$ Long). Mentuemhat was a great official in Thebes during reigns of Taharka and Psammetichus I (Leclant, 1961). Sample is archaeologically sealed to period 689 to 610 B.C. (end XXVth-beginning XXVIth Dynasties). Coll. 1967 by G. T. Martin (Sample 5/67). Age based on 5730 yr half-life $2520 \pm 72,570$ в.c.

\section{BM-335. Mentuhotep III}

$3670 \pm 75$ 1720 B.c.

$$
\delta C^{13}=-27.4 \%
$$

Wood from building ca. $90 \mathrm{~m} \mathrm{~W}$ of chapel of King S'ankh-Ka-rē' Mentuhotep III, (XIth Dynasty, ca. 2000 в.c.) on hill behind W Thebes, Egypt $\left(25^{\circ} 41^{\prime} \mathrm{N}\right.$ Lat, $32^{\circ} 40^{\prime} \mathrm{E}$ Long). Fragments of wood were lying on ground surface among broken mud-bricks, possibly remains of wooden columns (Petrie, 1909). Comparison of brick sizes suggests building was 
contemporary with S'ankh-Ka-rē' chapel. Coll. 1967 by G. T. Martin (Sample 6/67). Age based on 5730 yr half-life $3780 \pm 77,1830$ в.C.

\title{
BM-336. Tjanefer
}

\author{
$2890 \pm 100$ \\ 940 в.c. \\ $\delta C^{13}=-14.4 \%$
}

Reed used as bonding between mud-brick courses of pyramidal chapel of tomb (No. 158) of Tjanefer, Third Prophet of Amun (Seele, 1959) at Dra' Abû el-Naga', Thebes, Egypt $\left(25^{\circ} 41^{\prime} \mathrm{N}\right.$ Lat, $32^{\circ} 40^{\prime} \mathrm{E}$ Long). Tjanefer flourished from reign of Seti II (1214 to 1208 B.c.), XIXth Dynasty to that of Ramasses III (1182 to 1151 B.c.), XXth Dynasty. Coll. 1967 by G. T. Martin (Sample 7/67). Age based on 5730 yr half-life $2970 \pm 103$, 1020 в.C.

\section{BM-337. Tjanefer}

$$
\begin{gathered}
\mathbf{3 0 8 0} \pm \mathbf{7 5} \\
\mathbf{1 1 3 0} \text { B.c. } \\
\delta C^{13}=-26.9 \% 0
\end{gathered}
$$

Wood (Acacia sp.) from branch embedded during construction in mud-brick superstructure of tomb (No. 158) of Tjanefer at Dra' Abû elNaga', Thebes, Egypt (25 $41^{\prime} \mathrm{N}$ Lat, $32^{\circ} 40^{\prime} \mathrm{E}$ Long). See BM-336, above. Coll. 1967 by G. T. Martin (Sample 8/67). Age based on 5730 yr half-life $3170 \pm 77,1220$ в.c.

\section{BM-338. Roma}

$3030 \pm 85$ 1080 B.C.

Wood (Tamarix sp.) from branch embedded during construction in mud-brick superstructure of pyramidal chapel of tomb (No. 283) of Roma, High Priest of Amun (Fisher, 1924) at Dra' Abû el-Naga', Thebes, Egypt (25 $41^{\prime} \mathrm{N}$ Lat, $32^{\circ} 40^{\prime} \mathrm{E}$ Long). Roma flourished during reign of Ramasses II, XIXth Dynasty, ca. 1250 B.c. Coll. 1967 by G. T. Martin (Sample 9/67). Age based on 5730 yr half-life $3120 \pm 88,1170$ B.c.

\section{BM-339. Bekenkhons}

$$
1210 \pm 110
$$

Reed used as bonding between mud-brick courses, $\mathrm{S}$ side of pyramidal chapel, tomb (No. 35) of Bekenkhons, High Priest of Amun (Fisher, 1924) at Dra' Abû el-Naga', Thebes, Egypt $\left(25^{\circ} 41^{\prime} \mathrm{N}\right.$ Lat, $32^{\circ}$ $40^{\prime} \mathrm{E}$ Long). Bekenkhons was almost certainly the son of Roma (see BM-338, above) and also dates to reign of Ramasses II. Coll. 1967 by G. T. Martin (Sample 10/67). Comment: date is ca. $2000 \mathrm{yr}$ later than expected historical age. Re-examination of site revealed that sample came from a later Coptic wall and not from original wall of Tomb 35. Sample has also been checked by Pennsylvania lab., $1125 \pm 40$, A.D. 835 (Stuckenrath, 1968, written commun.).

\section{BM-340. Nectanebo}

$$
\begin{array}{r}
2310 \pm 80 \\
\mathbf{3 6 0} \text { B.C. } \\
\delta C^{13}=-14.9 \%
\end{array}
$$

Reed used as bonding between mud-brick courses of enclosure wall 
of Great Temple of Amun (Nims, 1965) at Karnak, Thebes, Egypt (25 $41^{\prime} \mathrm{N}$ Lat, $32^{\circ} 40^{\prime} \mathrm{E}$ Long). Dated on evidence of brick stamps to reign of Nectanebo I, XXXth Dynasty, 380 to 363 в.c. Coll. 1967 by G. T. Martin (Sample 11/67). Age based on 5730 yr half-life $2380 \pm 83,430$ в.c.

\section{Intef}

Five samples from complex of tomb (No. 386) of Overseer of Soldiers, Intef (Arnold and Settgast, 1965) at Asasif, Thebes, Egypt (25 $41^{\prime} \mathrm{N}$ Lat, $32^{\circ} 40^{\prime} \mathrm{E}$ Long). Dated to the late XIth to early XIIth Dynasties ca. 2000 в.C. Intef was a contemporary of Neb-hepet-re Mentuhotep I (XIth Dynasty). Coll. 1963-1967 by J. Settgast, Deutsches Archäol. Inst. Wooden dowels, coll. 1966, from debris outside tomb of Intef were dated by UCLA-1211, $3500 \pm 60,1550$ в.c. (Berger and Libby, 1967).

\section{BM-341. Intef}

$$
\begin{array}{r}
\mathbf{3 5 0 0} \pm \mathbf{7 0} \\
\mathbf{1 5 5 0} \text { B.C. } \\
\delta C^{13}=-25.5 \%
\end{array}
$$

Flax cloth (linen) from entrance to Tomb $\mathrm{T}, \mathrm{N}$ side of courtyard of tomb of Intef (Sample 12/67). Age based on 5730 yr half-life $3610 \pm$ 72, 1660 B.C.

\section{BM-342. Intef}

$3660 \pm 70$ 1710 B.C.

$$
\delta C^{13}=-27.1 \%
$$

Charcoal (Sample 13/67) from entrance to Tomb T, N side of courtyard of tomb of Intef. Age based on $5730 \mathrm{yr}$ half-life $3770 \pm 72,1820$ B.c.

\section{BM-343. Intef}

$\mathbf{3 7 2 0} \pm 85$

1770 в.c.

$$
\delta C^{13}=-27.6 \%
$$

Wood (Ficus sp., probably $F$. sycamorus L), probably fragment of a coffin, from inner part of Tomb $\mathrm{T}, \mathrm{N}$ side of courtyard of tomb of Intef (Sample 14/67). Age based on 5730 yr half-life $3830 \pm 88,1880$ в.c.

\section{BM-344. Intef}

$2610 \pm 70$

660 B.C.

$\delta C^{13}=-25.9 \%$

Fragment of wood (Pinus sp., probably $P$. pinea L) from burial chamber of tomb (No. 386) of General Intef (coll. 1963-64, Sample $15 / 67)$. Burial chamber was re-used for a later burial of the Saite period (XXVIth Dynasty, ca. 600 в.c.). Age based on 5730 yr half-life $2680 \pm$ 72, 730 B.c. Comment: sample is clearly from funerary equipment of the later burial. See BM-345, below.

\section{BM-345. Intef}

$$
\begin{gathered}
2580 \pm 100 \\
630 \text { B.C. } \\
\delta C^{1 s}=-27.8 \%
\end{gathered}
$$

Fragment of wood (Ficus sp., probably $F$. sycamorus L) from burial chamber of tomb (No. 386) of General Intef (coll. 1963-64, Sample 16/ 
67). Age based on 5730 yr half-life $2650 \pm 103$, 700 B.c. See BM-344, above.

BM-346. Haishetef

$3860 \pm 80$

1910 B.c.

$\delta C^{13}=-25.6 \%$

Reed (Sample 17/67) used as bonding between mud-brick courses, E side of mastaba of Haishetef near $S$ boundary wall of Zoser enclosure, Unas Pyramid cemetery, Sakkara, Egypt (29 $51^{\prime} \mathrm{N} \mathrm{Lat}, 31^{\circ} 14^{\prime} \mathrm{E}$ Long). Position of tomb in Unas Pyramid cemetery, fine workmanship of false door, and titles of tomb owner, indicate that it probably belongs to time of Unas, last king of the Vth Dynasty, (ca. 2350 в.C., although the last element of the name is typical of names of the First Intermediate Period, ca. 2200 в.c. Age based on 5730 yr half-life $3970 \pm 83$, 2030 в.c. Comment: result supports opinion that tomb dates to Old Kingdom rather than suggested later period for which a still younger date would be expected.

\section{BM-347. Gebelein}

$3650 \pm 80$

1700 B.C.

$\delta C^{13}=-27.8 \%$

Wood (Zizyphus sp., probably Z. lotus Lam) from a Middle Kingdom bow found at Gebelein, near Edfu, S of Luxor, Egypt $\left(24^{\circ} 58^{\prime} \mathrm{N}\right.$ Lat, $32^{\circ} 50^{\prime}$ E Long). Coll. 1967 by J. Settgast, (Sample 18/67). Tentatively dated to XIth Dynasty, ca. 2100 B.c. Age based on 5730 yr half-life 3750 $\pm 83,1800$ B.C.

\section{BM-381. Tell el Fara'in}

$2543 \pm 70$

593 B.c.

$\delta C^{13}=-26.7 \%$

Reed (ref. Site B, Dd 25) used as bonding between mud-brick courses of temple wall at Tell-el Fara'in, Buto, Egypt $\left(31^{\circ} 12^{\prime} \mathrm{N}\right.$ Lat, $30^{\circ}$ 45' E Long). Coll. 1967 by M. V. Seton-Williams, Egypt Explor. Soc. Age based on 5730 yr half-life $2619 \pm 72,669$ в.c. Comment: measurement was intended to date construction of wall of Buto considered to belong to Saite period (Seton-Williams, 1965, 1966, 1969). Date is lst proof of this, apart from a stone fragment bearing the name of a Saite king (Amasis I) found after sample was subm. and confirms expected age of ca. $664-525$ B.c.

\section{BM-401. Ptahshepses}

$3892 \pm 64$ 1942 B.c.

$$
\delta C^{13}=-25.5 \%
$$

Wood (Acacia sp., probably A. nilotica L) forming part of dowel found in situ in base of $\mathrm{N}$ column of portico of tomb of the vizier Ptahshepses (Vth Dynasty, reign of Niuserre, ca. 2450 в.c.) at Abu Sir, Egypt $\left(29^{\circ} 54^{\prime} \mathrm{N}\right.$ Lat, $31^{\circ} 12^{\prime} \mathrm{E}$ Long). Sample is archaeologically sealed to reign of King Niuserre. Coll. 1961 by Z. Žába, Czech. Inst. of Egyptol. (Sample 19/67). Age based on 5730 yr half-life $4006 \pm 66$, 2056 в.c. 


\section{BM-507. Sakkara}

Reed used as bonding between mud-brick courses of superstructure, Tomb 3518 at Sakkara Archaic Cemetery, Sakkara, Egypt $\left(29^{\circ} 51^{\prime} \mathrm{N}\right.$ Lat, $31^{\circ} 14^{\prime} \mathrm{E}$ Long). Tomb is dated absolutely to reign of Zoser, IIIrd Dynasty, ca. 2650 B.c. Coll. 1969 by G. T. Martin (Sample 1/69). Age based on 5730 yr half-life $4165 \pm 61,2215$ в.c.

\section{BM-508. Sakkara}

$4106 \pm 60$ 2156 B.C.

$\delta C^{13}=-27.0 \%$

Flax rope found in undisturbed fill of $\mathrm{S}$ shaft of Tomb 3518 at Sakkara Archaic Cemetery, Sakkara, Egypt $\left(29^{\circ} 51^{\prime} \mathrm{N}\right.$ Lat, 31 ${ }^{\circ} 14^{\prime} \mathrm{E}$ Long). Tomb is dated absolutely to reign of Zoser, IIIrd Dynasty, ca. 2650 в.c. Coll. 1969 by G. T. Martin (Sample 2/69). Age based on 5730 yr half-life $4226 \pm 61,2276$ B.C.

\section{BM-509. Sakkara}

$$
\begin{array}{r}
2243 \pm 60 \\
293 \text { B.C. } \\
\delta C^{13}=-29.1 \% \text {. }
\end{array}
$$

Cloth wrapped round a papyrus document dated to yr 11 of Darius I (XXVIIth Dynasty, reigned 521-486 в.c.) at Sakkara Archaic Cemetery, Sakkara, Egypt (29 $51^{\prime} \mathrm{N}$ Lat, $31^{\circ} 14^{\prime} \mathrm{E}$ Long). Papyrus and wrapping were probably contemporary. Coll. 1968 by G. T. Martin (Sample 3/69). Age based on 5730 yr half-life $2311 \pm 61$, 361 в.c.

\section{BM-510. Sakkara}

$$
\begin{gathered}
2361 \pm 60 \\
411 \text { в.c. } \\
\delta C^{13}=-23.1 \%
\end{gathered}
$$

Seeds from house from Coptic community built over courtyard of a series of shrines probably dating to Nectanebo II (XXXth Dynasty, ca. $360-343$ в.c.) at Sakkara, Egypt (29 $51^{\prime} \mathrm{N}$ Lat, $31^{\circ} 14^{\prime} \mathrm{E}$ Long). Adjacent houses were dated on numismatic evidence to last quarter of 4th century A.D. Coll. 1968 by G. T. Martin (Sample 4/69). Comment: date is ca. 800 yr earlier than expected; material dated is probably derived from supposed XXXth Dynasty shrines.

\section{BM-511. Sakkara}

$2972 \pm 60$ 1022 B.C.

Wood (Pinus sp.) from sarcophagus from grave cut into superstructure of Tomb 3518 at Sakkara Archaic Cemetery, Sakkara, Egypt $\left(29^{\circ} 51^{\prime} \mathrm{N}\right.$ Lat, $31^{\circ} 14^{\prime} \mathrm{E}$ Long). Grave contained pottery vessels including a fragment of Cypriote Base-ring I juglet, indicating date of early- to mid-XVIIIth Dynasty; also 2 dom-palm nuts. Coll. 1969 by G. T. Martin (Sample 5/69). Age based on 5730 yr half-life $3060 \pm 61$, 1110 B.c. Comment: see BM-512, below. 


\section{BM-512. Sakkara}

Dom-palm nut shells from grave cut into superstructure of Tomb 3518, Sakkara Archaic Cemetery, Sakkara, Egypt (29 $51^{\prime} \mathrm{N}$ Lat, $31^{\circ} 14^{\prime}$ E Long). Pottery in grave suggested early- to mid-XVIIIth Dynasty date (see BM-511, above). Coll. 1969 by G. T. Martin (Sample 6/69). Age based on 5730 yr half-life $2997 \pm 50,1047$ в.c. Comment: although assoc. pottery indicates date of ca. 1400 в.c., there is nothing else to date grave closely. Agreement between BM-511 and BM-512 suggests that Cypriote Base-ring juglet may have been re-used.

\section{BM-530. Fayum}

$5388 \pm 45$ 3438 B.C.

$$
\delta C^{13}=-29.9 \%
$$

Wood from part of a stick from Fayum 'A' neolithic site, Fayum, Egypt (29 $30^{\prime} \mathrm{N}$ Lat, $30^{\circ} 30^{\prime} \mathrm{E}$ Long) excavated by Gertrude CatonThompson about 1925. Stick is in Dept. of Egyptian Antiquities colln., British Mus., (Caton-Thompson and Gardner, 1934, v. I, p. 45-46; v. II, pl. XXIX (2) ). Subm. by I. E. S. Edwards, British Mus. Measurement made as check on original radiocarbon dates for Fayum 'A' (cereal grain, C-457, $6095 \pm 250$; C-550-551, $6391 \pm 180$; Libby, 1952, p. 70-71) and for comparison with 6 th millennium B.c. dates obtained recently for some similar 'neolithic' cultures of S Libyan and Saharan deserts (CatonThompson, 1969, written commun.). Animal bones, the only other organic material now available from excavation (Caton-Thompson and Gardner, 1934, v. I, p. 34) had no remaining organic content. Wood from stick was carefully pretreated for complete removal of paraffin wax used as a preservative. Age based on 5730 yr half-life $5550 \pm 46$, 3600 в.C. Comment: date earlier than 5000 в.c. was suggested for Fayum culture in "The Desert Fayum" (p. 93). This now appears an overestimate though there is abundant evidence elsewhere for primitive agriculture in 7 th and 8 th millennia B.c. Fayum 'A' was probably contemporary in part with pre-Dynastic cultures in Nile valley.

\section{Ethiopia}

$$
198 \pm 40
$$

\section{BM-636. Debra Damo}

\section{A.D. 1752}

Wood (Olea sp., possibly O. europaea) from Monastery Church of Debra Damo, N Ethiopia (14 $23^{\prime} \mathrm{N}$ Lat, $39^{\circ} 18^{\prime} \mathrm{E}$ Long). Sample is from part of the exposed end of a 'binder' penetrating one of the walls. Coll. 1948 by D. H. Matthews; subm. by D. R. Buxton, Fac. of Oriental Studies, Univ. of Cambridge. Comment: the Church, which was founded in early Christian times and had probably assumed its present form by 10th century A.D., appears to have had extremely complicated history with several periods of dilapidation and re-building (Buxton, 1946, 1947; Matthews, 1949; Matthews and Mordini, 1959). Re-building or, at least, repairs were still being done in 18th century. 


\section{Germany}

\section{BM-373. Köstritz}

$1480 \pm 125$

Collagen separated from a human bone fragment found at ca. $15 \mathrm{~m}$ depth in Pleistocene gravels below bones of Rhinoceros at Köstritz, Gera Dist., Thüringen, E Germany $\left(50^{\circ} 56^{\prime} \mathrm{N}\right.$ Lat, $12^{\circ} 01^{\prime} \mathrm{E}$ Long). Coll. 1820 by Dr. Schammerring; subm. by K. P. Oakley, British Mus. (Nat. Hist.). Comment: sample was dated because specimen is listed in the forthcoming pub. (Oakley and Campbell, in press). It is oldest discovered human bone fragment in colln. of British Mus. (Nat. Hist.) and was formerly considered ancient (Hess von Wichdorff, 1931). Date shows that it was an intrusive fragment only of historic interest in view of early date at which alleged assoc. with a locally extinct animal species was noted (von Schlotheim, 1820).

\section{E. Great Britain}

Under this heading, measurements have been divided into groups of period or type of problem. Within each group, dates are listed in BM- number order.

\section{Upper palaeolithic}

\section{Anston Stones cave series}

Collagen separated from animal bone fragments and reindeer antler (id. by K. Joysey, Dept. of Zool., Univ. of Cambridge) from Creswellian horizons beneath a thick stalagmite layer in Anston Stones cave (Dead Man's cave), Anston, S Yorkshire, England (53 $20^{\prime} 41^{\prime \prime} \mathrm{N}$ Lat, $1^{\circ} 12^{\prime}$ 18" W Long). Natl. Grid Ref. SK 529834. Coll. 1967 and 1968 by G. White and M. Dolby; subm. by P. A. Mellars, Univ. of Newcastle upon Tyne. (See Mellars, 1969.)

\section{BM-439. Anston Stones cave}

Bone fragments including reindeer (Sample 1, Sec. I, Spit 9), directly assoc. with characteristic Creswellian flint artifacts.

\section{BM-440a. Anston Stones cave}

$9940 \pm 115$

7990 в.c.

Bone fragments (Sample 2, Sec. I, Spit 9) within 0.6 to $1 \mathrm{~m}$ of Creswellian flints at same horizon but not in immediate assoc.

\section{BM-440b. Anston Stones cave}

Reindeer antler fragment (Sample 3, Sec. XVII, Spit 6) not in direct assoc. with Creswellian flints but probably from same horizon.

General Comment (P.A.M.): dates are satisfactory and are 1000-3000 yr older than those previously available from a Creswellian site-Mother Grundy's Parlour, Creswell Crags (Godwin and Willis, 1962, p. 61) and indicate that earlier stages of Creswellian industry belong to early part of postglacial period. 
BM-497. Badger Hole

Collagen separated from mammalian bone fragments (ref. Samples I, II, and III) from layer (C3) of firm reddish sandy silt resting on bedrock and probably representing an interstadial formation (possibly end of Upton Warren interstadial complex ca. 23,000 yr B.P.) in cave site of Badger Hole (McBurney, 1960) $70 \mathrm{~m} \mathrm{~S}$ from Wookey Hole, Mendip, Somerset, England ( $51^{\circ} 13^{\prime} 42^{\prime \prime} \mathrm{N}$ Lat, $2^{\circ} 40^{\prime} 12^{\prime \prime}$ W Long). Natl. Grid Ref. ST 532479. Sample assoc. with undisturbed 'proto-Solutrean' point and indirectly with 2 human mandibular fragments. Coll. 1968 and subm. by J. B. Campbell, Jr., Pitt Rivers Mus., Oxford. Comment (H.B. and R.B.): small size of sample $(<0.5 \mathrm{gm}$ benzene) determined detectable age limit, older than $18,000 \mathrm{yr}$.

\section{BM-524. Sun Hole}

$12,378 \pm 150$ 10,428 в.c.

Collagen separated from humerus of Ursus arctos (Find 66) from upper thermoclastic scree in entrance to Sun Hole cave, Cheddar Gorge, Mendip, Somerset, England (51 $16^{\prime} 59^{\prime \prime} \mathrm{N}$ Lat, $2^{\circ} 45^{\prime} 50^{\prime \prime} \mathrm{W}$ Long). Natl. Grid Ref. ST 467541. Same layer of scree previously yielded ca. 50 Creswellian flints (Tratman, 1955). Sample $80 \mathrm{~cm}$ from nearest 2 diagnostic flints (including trapezoidal point and borer), was intended to date Creswellian industry at Sun Hole; approx. age of similar industry at Soldier's Hole and more prolific industries at Gough's cave and Flint Jack's cave in same area. Coll. 1968 and subm. by J. B. Campbell, Jr.

Mesolithic

BM-447. Cherhill

$7230 \pm 140$ 5280 в.c.

Charcoal from base of tufa deposit overlying Mesolithic occupation site at Cherhill, Wiltshire, England (51 $1^{\circ} 26^{\prime} \mathrm{N}$ Lat, $1^{\circ} 57^{\prime} \mathrm{W}$ Long). Natl. Grid. Ref. SU 031701. Dates Mesolithic industry of Sauvetterian type, onset of tufa formation, and beginning of Atlantic period (Zone VIIa). Coll. 1967 and subm. by J. G. Evans, Inst. of Archaeol., Univ. of London. Comment (J.G.E.): date compares well with Scaleby Moss series for Boreal/Atlantic transition (Zone VI/VIIa) Q-166, 6955 \pm 131, Zone VIIa base; Q-165, $7432 \pm 350$, Zone VI/VII boundary; Q-167, $7361 \pm 146$, Zone VI top (Godwin et al., 1957). Only Flandrian tufa date (ox bone) is Blashenwell, BM-89, $6450 \pm 150$, middle zone of tufa (Barker and Mackey, 1961). Date for base of tufa at Cherhill reinforces idea that onset of tufa formation coincided with beginning of Zone VIIa (see Kerney et al., 1964). Preliminary assessment of flint industry suggests that it is of mixed origins and consists of basically Maglemosian assemblage with small proportion of microlithic forms with Sauvetterian affinities (cf. Wainwright, 1963, p. 114). Other relevant dates are: for Sauvetterian industry at Shippea Hill, Cambridgeshire (Zone VIc), Q-587, $7610 \pm 150$ (Godwin and Willis, 1962, p. 57), and for westward extension of Maglemosian, Freshwater West, Pem- 
brokeshire (Zone VII), Q-530, $5960 \pm 120$ (Godwin and Willis, 1964, p. 127).

\section{BM-473. Culverwell}

$7150 \pm 135$ 5200 B.c.

Charcoal from Mesolithic occupation site at Culverwell, Portland Bill, Isle of Portland, Dorset, England (50 31' $27^{\prime \prime} \mathrm{N}$ Lat, $2^{\circ} 26^{\prime} \mathrm{W}$ Long). Natl. Grid Ref. SY 685694. Samples were from Level 2, Spit 5 near base of a large shell midden. Level 2 was $30 \mathrm{~cm}$ below hut floor of limestone slabs which sealed part of midden (Palmer, 1969). Coll. 1968 and subm. by Susann Palmer. Comment (S.P.): Portland site is characterized by numerous pointed chert picks found in situ in a Mesolithic context for 1st time in England. Similar picks occur in early phases of Maglemosian culture of Denmark, e.g., in Melstedt group of Bornholm, K-586, $8190 \pm 130,6240$ B.c. (Becker, 1951; Tauber, 1960, p. 22). Microlithic industry of site is comparable with Cherhill, BM-447, $7230 \pm 140$, above, (see also Palmer, 1970).

Neolithic and Beaker

\section{BM-205. Knap Hill}

$4710 \pm 115$

Collagen separated from red deer antler (Ref. $\mathrm{K} / \mathrm{l} / 6 / \mathrm{Al}$.) from Neolithic causewayed camp at Knap Hill, Alton Priors, Wiltshire, England ( $51^{\circ} 22^{\prime} \mathrm{N}$ Lat, $1^{\circ} 50^{\prime} \mathrm{W}$ Long). Natl. Grid Ref. SU 121636. From primary silt of rock-cut chalk ditch of Windmill Hill phase, sealed by 1 to $2 \mathrm{~m}$ of undisturbed deposits (Connah, 1965). Coll. 1961 and subm. by G. E. Connah. Comment (G.E.C.): date agrees well with expected age and compares well with NPL-76, $2790 \pm 90$ в.c. (Callow et al., 1965, p. 158) for similar site at Hambledon Hill, Dorset and with BM-74, $2580 \pm 150$ B.c. (Barker and Mackey, 1961, p. 42) for similar site and context at Windmill Hill, Wiltshire (see also Connah, 1969a, b).

\section{BM-208. Knap Hill}

Charcoal (Ref. K/II/4) from Neolithic causewayed camp at. K.

(Ref. K/II/4.) from Neolithic causewayed camp at Knap Hill, Alton Priors, Wiltshire, England (51 ${ }^{\circ} 22^{\prime} \mathrm{N}$ Lat, $1^{\circ} 50^{\prime} \mathrm{W}$ Long). Natl. Grid Ref. SU 121636. From top of ditch sec. from mixture of rubble and humus with Necked Beaker sherds, sealed by ca. $30 \mathrm{~cm}$ undisturbed soil (Connah, 1965). Coll. 1961 and subm. by G. E. Connah. Comment (G.E.C.): date agrees well with expected age and compares well with BM-133, $1850 \pm 150$ B.c. (Barker and Mackey, 1963, p. 105) for a similar Beaker assemblage at Fifty Farm, Suffolk (see also Connah, 1969a, b).

\section{BM-254. Brook}

$4540 \pm 105$

Charcoal (converted by Cambridge lab. to $\mathrm{BaCO}_{3}$; Godwin, 1965, written commun.) from Devil's Kneading Trough, Brook, Kent, England $\left(51^{\circ} 10^{\prime} \mathrm{N}\right.$ Nat, $0^{\circ} 58^{\prime} \mathrm{E}$ Long). Natl. Grid Ref. TR 077452. From Hori- 
zon $\mathrm{C}, 81$ to $101 \mathrm{~cm}$ in weak fossil soil within chalky hill washes filling valley bottom (Kerney et al., 1964, fig. 12). Coll. 1963 by M. P. Kerney, Dept. of Geol., Imperial College, Univ. of London; subm. by H. Godwin. Comment (M.P.K.): dates level of drastic vegetational clearance on chalk escarpment, as revealed by changes in a molluscan diagram (Kerney et al., 1964, fig. 14). Horizon assoc. with Neolithic flint industry; sherds of Neolithic A pottery occur at slightly deeper level (id. 1968 by I. H. Longworth). Signs of clearance already appear at these lower levels. No comparably dated Neolithic clearance horizon is yet available in Kent but a pollen diagram and assoc. radiocarbon dates from Wingham, near Canterbury (Godwin, 1962) showed large scale deforestation at least as early as ca. 1700 B.c. when peat formation began locally. Peat appeared to overlie deposit from which Neolithic A pottery was previously obtained.

\section{BM-293. Kilham Long Barrow}

Charcoal from horizontal timber used as packing material behind vertical posts set in a bedding trench at $\mathrm{E}$ end of mortuary enclosure Kilham Long Barrow, Kilham, near Bridlington, Yorkshire, England $\left(54^{\circ}\right.$ $03^{\prime} \mathrm{N}$ Lat, $0^{\circ}$ 23' W Long). Natl. Grid Ref. TA 055673. Coll. 1965 and subm. by T. G. Manby, Doncaster Mus. Comment (T.G.M.): trapezoidal mortuary enclosure at Kilham closely resembles enclosure at Fussell's Lodge Long Barrow (Ashbee, 1966) dated by BM-134, $3230 \pm 180$ B.C. (Ashbee, 1964).

\section{Abingdon series}

Charcoal, bone, and antler from phases of Inner Ditch of Neolithic causewayed camp at Abingdon, Berkshire, England $\left(51^{\circ} 40^{\prime} \mathrm{N}\right.$ Lat, $1^{\circ}$ 17' W Long). Natl. Grid Ref. SU 511983. Coll. 1963-1964 by D. M. E. Avery and H. J. Case; subm. by H. J. Case, Ashmolean Mus., Oxford. (See Leeds, 1927, 1928; Case, 1956.)

\section{BM-348. Abingdon}

$4730 \pm 135$

Sample 1, charcoal, Area B, Phase II (AB64, B9 : 4).

\section{B.C.}

\section{BM-349. Abingdon}

$6020 \pm 110$

4070 в.c.

Sample 2, charcoal, Area B, Phase IV (AB 64, B10:2).

BM-350. Abingdon

$4910 \pm 110$

2960 в.c.

Sample 3, charcoal, Area C, Phase IIc (AB, C2 : 29).

BM-351. Abingdon

$5060 \pm 130$

3110 B.c.

Sample 4, charcoal, Area C, Phase IIe (AB, C2 : 27). 
BM-352. Abingdon

2760 B.C.

Sample 5, bone (collagen), Area C, Phase IIe (AB, C2 : 27, Bos).

BM-353. Abingdon

$4970 \pm 130$

Sample 6, charcoal, Area C, Phase IV (AB, C2 : 26).

\section{BM-354. Abingdon}

$4450 \pm 145$

Sample 7, bone (collagen), Area C, Phase IV (AB, C2 : 23A, Bos).

\section{BM-355. Abingdon}

$4460 \pm 140$

2510 B.C.

Sample 8, antler (protein), Area C, Phase IV (AB, C2 : 4, Red deer). General Comment: several samples from different levels ('phases') in 2 areas, B and C, of Inner Ditch of causewayed camp at Abingdon were dated. Phases of Area B are not the same as those of Area C, Phase II is a primary or early occupation in both areas, probably of ca. $300 \mathrm{yr}$ duration. Phase IV is a later occupation in both areas although date for Sample 6 (BM-353) from this phase is comparable with dates for Phase II. Sample 2 (BM-349, weighted mean of 2 closely comparable measurements) is ca. $1000 \mathrm{yr}$ earlier than any known site of this kind in Britain and must relate to intrusive older material not belonging to causewayed camp. Apart from BM-349, all dates are fully within early to middle Neolithic period (G. de G. Sieveking, British Mus., 1968, written commun.).

\section{South Street Long Barrow}

Charcoal, bone, and antler from South Street Long Barrow (G. 68), Avebury, near Marlborough, Wiltshire, England $\left(51^{\circ} 25^{\prime} \mathrm{N}\right.$ Lat, $1^{\circ} 52^{\prime}$ W Long). Natl. Grid Ref. SU 090692. Samples, from a primary context, date construction of barrow (Smith and Evans, 1968) and Neolithic plough marks beneath it (Fowler and Evans, 1967); also compare antler, bone, and charcoal as dating materials. Coll. 1966 and subm. by J. G. Evans.

BM-356. South Street

Charcoal (Ave. G 68 i) from surface of buried soil beneath mound.

\section{BM-357. South Street}

$4700 \pm 135$

Collagen separated from cervical vertebra of ox (Ave. G. 68 ii) from coarse primary chalk fill at bottom of $\mathrm{N}$ ditch.

BM-358a. South Street

$4620 \pm 140$

2670 B.C.

Protein separated from red deer antler (Ave. G. 68 iii) from coarse primary chalk fill at bottom of $\mathrm{N}$ ditch. 
BM-358b. South Street

Protein separated from red deer antler (Ave. G. 68 iv) embedded in mound.

General Comment: dates construction of barrow in 1st half of $3 \mathrm{rd}$ millennium B.c. and compares well with dates for 2 other long barrows in area, Nutbane, BM-49, $2730 \pm 150$ B.c. (Vatcher, 1959) and Wayland's Smithy, I-1468, $2830 \pm 130$ B.c. (Atkinson, 1965). Age is minimum for Neolithic plough marks on buried ground surface beneath barrow. Results for different materials are indistinguishable within limits of error of dates (Evans and Burleigh, 1969).

\section{BM-370. Pinnacle}

$5020 \pm 110$

3070 B.c.

Charcoal assoc. with Danubian type Neolithic pottery from Pinnacle, Jersey, Channel Is. (49 $14^{\prime} 55^{\prime \prime}$ N Lat, $2^{\circ} 15^{\prime} 9^{\prime \prime}$ W Long). (See Hawkes, 1937; Godfray and Burdo, 1949.) Coll. ca. 1935 by A. D. B. Godfray; subm. by J. T. Renouf, Soc. Jersiaise Mus.

\section{Durrington Walls}

Charcoal, bone, and antler from Neolithic henge monument of Durrington Walls, Wiltshire, England (51 $11^{\circ} 12^{\prime} \mathrm{N}$ Lat, $1^{\circ} 47^{\prime} \mathrm{W}$ Long). Natl. Grid Ref. SU 150437. (See Crawford, 1929; Stone et al., 1954.) Samples date Phase 2 of S Circle and assoc. domestic debris, construction of main henge ditch and assoc. late Neolithic flints, and pottery from bottom of ditch (Wainwright, 1967; 1968). Samples also compare antler, bone, and charcoal as dating materials. Coll. 1967 and subm. by G. J. Wainwright, Min. of Pub. Bldg. and Works.

BM-395. Durrington Walls

Fe $\mathrm{B}$ 92 : S Circle : Phase 2 . antler (675028) from packing material of a posthole.

BM-396. Durrington Walls

Fe B 92 : S Circle : Phase 2. Oak charcoal (675029) from packing material of a posthole.

BM-397. Durrington Walls

Fe B 92 : S Circle : Phase 2. Collagen separated from animal bone (675030) from packing material of a posthole.

BM-398. Durrington Walls

$3927 \pm 90$

1977 B.c.

Ditch (7). Charcoal (675032) from base of main enclosure ditch. 
BM-399. Durrington Walls

$3965 \pm 90$

2015 B.C.

Ditch (7). Collagen separated from animal bone (675033) from base of main enclosure ditch.

BM-400. Durrington Walls

Ditch (7). Protein separated from Red Deer antler (675034) from base of main enclosure ditch.

General Comment: dates conform with expected age and show contemporaneous construction of timber structure known as S Circle and digging of main enclosure ditch. Later hearths and Beaker pottery in main enclosure ditch were dated by BM-285, $1610 \pm 120$ B.C. and BM-286, $1680 \pm 110$ в.c. (Barker, Burleigh, and Meeks, 1969a, p. 288). Results for different sample materials are indistinguishable within limits of error of dates. A report of excavation will appear later (Wainwright et al., in press).

\section{BM-442. Embo}

$3870 \pm 100$

Collagen separated from various small animal bones (ref. CnIa; id. by A. S. Clark, see Soc. Antiquaries of Scotland Proc., v. 96, p. 35) from a chambered cairn at Embo, Sutherland, Scotland ( $57^{\circ} 54^{\prime} 28^{\prime \prime} \mathrm{N}$ Lat, $3^{\circ}$ $59^{\prime} 45^{\prime \prime}$ W Long). Natl. Grid Ref. NH 817926. Bones were contemporary with construction of cairn as their location would have been inaccessible after cairn was completed (Henshall and Wallace, 1965). Coll. 1960 by Audrey S. Henshall; subm. by H. McKerrell, Natl. Mus. Antiquities of Scotland, Edinburgh. Comment (A.S.H.): 1st radiocarbon date for a Scottish passage grave. Construction date is uncertain and largely inferred from typologic considerations. Embo is relatively simple in plan and early date was expected (1st half of 3rd millennium B.c.) but tombs of this kind were possibly still being built to about beginning of 2nd millennium B.c.

BM-449. Wawcott

$5260 \pm 130$ 3310 B.C.

Decayed wood from hearth in undisturbed Mesolithic pit dwelling at Wawcott Farm, Kintbury, near Newbury, Berkshire, England $\left(51^{\circ} 24^{\prime} 22^{\prime \prime} \mathrm{N}\right.$ Lat, $1^{\circ} 26^{\prime} 28^{\prime \prime}$ W Long). Natl. Grid Ref. SU 389676. Coll. 1966 by F. R. Froom; subm. by R. A. Rutland, Reading Mus. Comment (R.A.R.): 1st date for this series in Kennet Valley. Only other local Mesolithic dates are for Thatcham (Churchill, 1962) but flint industries at the 2 sites are entirely different (see Wymer, 1962; Froom, $1963 ; 1964)$.

\section{BM-450. Playden}

$3690 \pm 115$

Charcoal from a Neolithic ring-ditch settlement (Cheney, 1935) at Playden Site 'A', Mockbegger, near Rye, Sussex, England $\left(50^{\circ} 56^{\prime} \mathrm{N}\right.$ Lat, $0^{\circ} 43^{\prime}$ E Long). Natl. Grid Ref. TQ 920210. Coll. ca. 1930 by H .J. 
Cheney; subm. by G. de G. Sieveking, British Mus. Comment (G.de G.S.): late Neolithic date agrees well with age indicated by pottery from this site which belongs to a late Neolithic-Beaker assemblage (see Wainwright, 1967, p. 182-183).

\section{BM-493. Cherhill}

$4715 \pm 90$

Charcoal (Ref. CH/67/X; Corylus sp., id. by Joan Sheldon) from Neolithic Ditch I, possibly a borrow pit for daub, at foot of Chalk escarpment at Cherhill, Wiltshire, England (51 $26^{\prime} \mathrm{N}$ Lat, $1^{\circ} 57^{\prime} \mathrm{W}$ Long). Natl. Grid Ref. SU 031701. Charcoal was from large burnt plank in upper levels of fine primary fill of ditch and was assoc. with pottery assemblage of Windmill Hill type (Evans and Smith, 1967). Coll. 1967 and subm. by J. G. Evans. Comment: dates assemblage of undecorated Neolithic pottery.

\section{BM-505. Normanton Down}

$4510 \pm 103$

Protein separated from antler pick from base of $\mathrm{N}$ bedding trench, E entrance, Normanton Down Long Mortuary Enclosure, Normanton Down, near Amesbury, Wiltshire, England $\left(51^{\circ} 10^{\prime} \mathrm{N}\right.$ Lat, $1^{\circ} 50^{\prime} \mathrm{W}$ Long). Natl. Grid Ref. SU 115411. Dates construction of enclosure (Vatcher, 1961, fig. 3, p. 163). Coll. 1959 and subm. by Faith de M. Vatcher, Alexander Keiller Mus., Avebury. Comment (F.deM.V.): date is at later end of presently available dates for unchambered long barrows, which are closest parallel, but consistent with sherd of Mortlake pottery near top of one of post trenches.

\section{Beckhampton Road Long Barrow}

Protein separated from Red Deer antler (Ref. A.7) from buried soil surface beside inner face of revetment bank, Beckhampton Road Long Barrow (G.76), Bishops Cannings, Wiltshire, England (51 $24^{\prime} 30^{\prime \prime} \mathrm{N}$ Lat, $1^{\circ} 54^{\prime} 10^{\prime \prime}$ W Long). Natl. Grid Ref. SU 067677. Antler was $15 \mathrm{~cm}$ below base of modern plough soil, overlain by a 2nd antler, both covered by undisturbed stacked turves. Dates construction of barrow; was one of many used as picks in quarrying material for mound and buried in it when no longer required. Coll. 1964 and subm. by Isobel F. Smith, Inspectorate of Ancient Monuments, Min. of Pub. Bldg. and Works.

\section{BM-506a. Beckhampton Road}

$4257 \pm 90$

Separated protein-no humic extraction.

\section{BM-506b. Beckhampton Road}

$4467 \pm 90$ 2517 B.C.

Separated protein-humic extraction with dilute alkali. Comment: dates compatible with those for Giants Hills Long Barrow, BM-191, $4410 \pm$ 150; 2460 в.c.; BM-192, $4320 \pm 150$; 2370 в.c. (Barker, Burleigh, and Meeks, 1969a, p. 287) and South Street Long Barrow, BM-356-BM-358b (Evans and Burleigh, 1969; see also above) and confirm that charcoal 
from beneath mound (NPL-138, $5200 \pm 160,3250$ в.c., unpub.) relates to earlier activity on site well before construction of barrow. Because of difference between BM-506a and NPL-138, a 2nd sample of collagen from same antler was extracted with alkali to remove possible younger contamination. The result, BM-506b, suggests that antler may have been somewhat contaminated, but date is still ca. 750 yr later than NPL-138.

\section{Lussa River}

Charcoal from occupation site at Lussa R., Isle of Jura, Argyllshire, Scotland (56 $06^{\prime} 18^{\prime \prime}$ N Lat, 5 $5^{\circ} 46^{\prime} 06^{\prime \prime}$ W Long). Natl. Grid Ref. NR 645873. Coll. 1969 and subm. by J. Mercer.

\section{BM-555. Lussa River}

\section{BM-556. Lussa River}

Sample 2. Comment: a full report on site will appear later (Mercer, ms. in preparation; see also Mercer, 1969, 1970).

Prehistoric trackways

\section{Westhay}

Wood from trackways at Westhay, Somerset, England $\left(51^{\circ} 11^{\prime} \mathrm{N}\right.$ Lat, $2^{\circ} 50^{\prime} \mathrm{W}$ Long). Natl. Grid Ref. ST 428423. Coll. 1967 by J. M. Coles and F. A. Hibbert; subm. by J. M. Coles, Univ. of Cambridge, for comparison with other Neolithic trackways in immediate area (see Godwin, 1960; Dewar and Godwin, 1963; Coles and Hibbert, 1968; Coles et al., 1970). Samples were pretreated with dilute acid and dilute alkali at Cambridge lab.

\section{BM-382. Westhay}

$4266 \pm 131$

Wood from stump in Bell track, lower level, in peat. (Sample A, Bell III. Ib, lower.)

\section{BM-383. Westhay}

$4021 \pm 103$

Bell track, peg from lower level, in peat. (Sample B, Bell III. Ib, lower.)

\section{BM-384. Westhay}

Bell track, tranverse bearer, upper level, in peat. (Sample C, Bell III. Ib, upper.)

\section{BM-385. Westhay}

$4450 \pm 110$

Peg from un-named trackway in peat. (Sample D, Baker I. 2.) 
BM-386. Westhay

$3934 \pm 111$

Abbot's Way track, tranverse bearer in peat. (Sample E, Godwin II. Abbot.)

General Comment: dates agree with stratigraphy and dated sequence of peat development in immediate area. Abbot's Way track also dated by GaK-1940, $4040 \pm 90$; Lu-298, $3940 \pm 65$; Q-926, $4018 \pm 80$ (all unpub.) and by Q-647, $4810 \pm 120,2860$ B.c. (Godwin and Switzur, 1966).

\section{Bronze age}

\section{Easington}

Charcoal and decayed wood from Round Barrow I, Easington, Yorkshire, England (53 $38^{\prime} 24^{\prime \prime} \mathrm{N}$ Lat, $0^{\circ} 07^{\prime} 48^{\prime \prime}$ E Long). Natl. Grid Ref. TA 409181. Charcoal (Sample A) assoc. with a clay hearth, large posthole, worked and waste flint, and sherds of pottery. Decayed wood (Samples $\mathrm{B}$ and $\mathrm{C}$ ) was from large timbers forming a circle ca. $16 \mathrm{~m}$ diam. passing over posthole (Sample A) and sealed by ca. $0.6 \mathrm{~m}$ clay hillwash from mound. Barrow contained an inhumation with large ' $V$ ' perforated jet button and undecorated beaker (Mackey, ms. in preparation). Coll. 1965 and subm. by R. W. Mackey, Hull Museums.

\section{BM-268. Easington}

$4354 \pm 165$

Sample A.

BM-269. Easington 2404 B.c.

Sample B.

\section{BM-270. Easington}

$3450 \pm 90$ 1500 B.c.

Sample C. Comment: BM-268 relates to Neolithic occupation on site a millennium earlier and is not related to construction of barrow.

\section{Ampleforth Moor}

Charcoal from old ground surface beneath a group of round barrows on Ampleforth Moor, N Yorkshire, England (54 $14^{\circ} \mathrm{N} \mathrm{Lat,} 1^{\circ} 6^{\prime}$ W Long). Natl. Grid Ref. SE 580800. Intended to date Bronze age fabrics and faience bead (Wainwright and Longworth, 1970). Coll. 1967 by G. J. Wainwright, Ministry of Pub. Bldg. and Works; subm. by I. H. Longworth, British Mus.

\section{BM-368. Ampleforth Moor}

$2487 \pm 90$

Charcoal beneath Barrow 7 .

\section{BM-369. Ampleforth Moor} 537 B.C.

Charcoal beneath Barrow 3. Comment (I.H.L.): expected age of faience bead was ca. 1400 B.C., but expected age of most of coarse ware was ca. 650 B.c. because of comparable pottery from Heathery Burn 
(British Mus. Colln.). Dates clearly relate to later coarse ware and not to earlier pottery fabrics (Grimston ware and possible plain Beaker) and faience bead incorporated in buried turf line.

\section{BM-441. Ness of Gruting}

$3514 \pm 120$

Carbonized grain (id. by H. Helbaek as barley, partly hulled, partly naked $(1: 3)$ and probably most northerly European early grain find; see Calder, 1958, p. 353). From cache of $28 \mathrm{lbs}$. found at base of filling of main stone wall of oval, Shetland-type house (House 1) with adjacent field system at Ness of Gruting, Sansting parish, Shetland $\left(60^{\circ} 13^{\prime} \mathrm{N}\right.$ Lat, $1^{\circ} 30^{\prime}$ W Long). Natl. Grid Ref. HU 281484. Late Beaker derived pottery and stone implements including 2 miniature battle axes of postBeaker or early Bronze-age type and a "sponge-finger" stone were found in house (Calder, 1958, p. 381-97) suggesting contemporaneity with Wessex culture of S England. Coll. 1952 by C. S. T. Calder; subm. by R. B. K. Stevenson, Natl. Mus. Antiquities of Scotland, Edinburgh.

Vitrified fort

\section{Cullykhan, Troup Head}

Charcoal and wood from Cullykhan vitrified fort, Troup Head, near Pennan, Banffshire, Scotland (57 $41^{\prime} 17^{\prime \prime} \mathrm{N}$ Lat, $2^{\circ} 17^{\prime} 26^{\prime \prime} \mathrm{W}$ Long). Natl. Grid Ref. NJ 616661. Coll. 1967 and 1969 by J. C. Greig, H. McKerrell, and E. W. Mackie; subm. by H. McKerrell, Natl. Mus. Antiquities of Scotland, Edinburgh (see Greig, 1970).

\section{BM-443. Cullykhan}

Charcoal (Sample 2) from surface of cobbled area outside fort.

\section{BM-444. Cullykhan}

Charcoal (Sample 9) from large beams within fort walls.

BM-445. Cullykhan

$1633 \pm 40$

Charcoal (Sample 13) from wooden object in 1st stratified occupation level.

BM-446. Cullykhan

$2337 \pm 65$

Charcoal (Samples 14, 15) from narrow burnt layer at top of 1st stratified occupation level.

\section{BM-639. Cullykhan}

Outer wood (Sample 20) from immediately beneath bark of large oak trunk from one of several post-holes originally forming part of massive defensive entrance to fort.

General Comment: BM-443 suggests date of last occupation of Late Bronze age palisaded settlement. BM-444 intended to date timber plat- 
form forming a foundation for vitrified wall of expected date ca. 100 B.c., but relates to material from much earlier context. BM- 445 dates horizon containing Roman pottery sherds of estimated date ca. 250 to 350 A.D. BM-446 dates occupation level of defensive gateway containing finds of Late Bronze age date, including numerous pottery sherds. BM639 dates construction of massive Late Bronze age gateway and agrees with BM-446.

Early iron smelting

\section{Minepit Wood}

Charcoal from early iron working site at Minepit Wood (Orznash), Withyham, Sussex, England (51 $56^{\circ} \mathrm{N}$ Lat, $0^{\circ} 10^{\prime} \mathrm{E}$ Long). Natl. Grid Ref. TQ 523338. Coll. 1964-1967 and subm. by J. H. Money, Sussex Archaeol. Soc. (see Straker, 1931; Money, 1966-1968).

BM-361. Minepit Wood

A.D. 1524

$426 \pm 40$

Charcoal (C.53) from old land surface near edge of small minepit, securely sealed by dump of clay excavated from pit.

\section{BM-363. Minepit Wood}

$1949 \pm 43$

Charcoal (C.16) assoc. with Iron age B pottery from bottom of pit covered by dump of clay when pit was filled in by workers of later smelting furnace dated, BM-267, $1610 \pm 150$, A.D. 340 (Barker, Burleigh, and Meeks, 1969a, p. 283).

BM-364. Minepit Wood

$$
532 \pm 100
$$

Charcoal (C.86) from debris of Furnace 5, an ore roasting furnace.

\section{BM-365. Minepit Wood}

$545 \pm 40$

Charcoal (C.105) from rectangular masonry and timber structure enclosing Furnaces 2 and 3 and probably contemporary with Furnace 2, a smelting furnace. Charcoal from large undisturbed deposit of prepared fuel.

\section{BM-366. Minepit Wood}

\section{A.D. 1380}

$570 \pm 44$

Charcoal (C.87) from upper part of undisturbed deposit of furnace debris on floor of Furnace 4, an ore roasting furnace, sealed by ca. 38 $\mathrm{cm}$ of soil.

General Comment (J.H.M.): BM-361 dates this type of small minepit as late Medieval; archaeologically, it could equally be Iron age. BM-363 is convincing, as assoc. type of Iron age pottery is assumed to date from 1st century B.C. to early lst century A.D.; it also suitably pre-dates Roman furnace, BM-267, $340 \pm 100$ A.D., built over these earlier workings. BM364-366 date roasting/smelting complex and are in good agreement. Results will be discussed in more detail later (Money, 1971). 


\section{BM-255. Caerwys skeleton}

Collagen separated from post-cranial human bone from almost complete skeleton (ref. Site G) in extensive tufa deposits near Caerwys, Flintshire, N Wales (53 $3^{\circ} 14^{\prime}$ N Lat, $3^{\circ} 22^{\prime}$ W Long). Natl. Grid Ref. SJ 138712. Coll. 1952 by B. H. Chorley; subm. by K. P. Oakley, British Mus. (Nat. Hist.). Comment: Caerwys tufa contains microlithic industry; skeleton was previously considered of Mesolithic age; if so would have been an important find and the most complete example known from Britain. At time of discovery original circumstances of burial could not be determined (Jackson, 1956). Date shows burial was relatively recent and most probably intrusive.

\section{BM-282. Branston skeleton}

$1110 \pm 125$

Collagen separated from part of diaphysis of right femur from skeleton of a young woman (id. by Sir Arthur Keith), discovered in 1943 during commercial gravel excavation at Branston, $3 \mathrm{~km}$ SW Burton-onTrent, Staffordshire, England (52 $47^{\prime} \mathrm{N}$ Lat, $1^{\circ} 40^{\prime} \mathrm{W}$ Long). Natl. Grid Ref. SK 212202. Coll. by A. L. Armstrong; subm. by K. P. Oakley, from Coventry Mus. colln. Bones scattered horizontally over ca. $4 \mathrm{~m}$ diam. area, were ca. $30 \mathrm{~cm}$ from base of peat layer ca. $0.75 \mathrm{~m}$ thick overlain by $0.75 \mathrm{~m}$ blue clay and $30 \mathrm{~cm}$ soil (Bemrose, 1953). Pollen analysis suggested date was Early postglacial (Godwin and Tallantire, 1966, written commun.). Platform of branches and logs with wooden causeway was found ca. $25 \mathrm{~m}$ from skeleton. Microliths and split animal bones were evidence of Mesolithic occupation. Comment: skeleton, if Mesolithic, would have been important, but it was an intrusive Dark age skeleton and not correlated with surrounding deposits or nearby trackway and platform.

\section{BM-458. Maiden Castle}

$1315 \pm 80$

Collagen separated from femora of human skeleton from Maiden Castle, Winterborne St. Martin, Dorset, England $\left(50^{\circ} 42^{\prime}\right.$ N Lat, $2^{\circ} 28^{\prime}$ W Long). Natl. Grid Ref. SY 669885. Skeleton was considered Neolithic primary burial (Ref. Q1; see Wheeler, 1943, p. 344-346), but injuries to bones are attributed to a metal sword. Coll. ca. 1936 by R. E. M. Wheeler; subm. by D. R. Brothwell, British Mus. (Nat. Hist.) from Dorset County Mus. colln. Comment: date, which appears to represent an intrusive Dark Age burial, settles a previous anomaly (Brothwell, ms. in preparation).

\section{BM-471. Aveline's Hole}

$9114 \pm 110$

Collagen separated from part of femora of human skeleton from Aveline's Hole, Burrington Combe, Mendip, Somerset, England $\left(51^{\circ}\right.$ 19' N Lat, $2^{\circ} 45^{\prime}$ W Long). Natl. Grid. Ref. ST 477587. Aveline’s Hole 
skulls were considered possibly of Younger Dryas (Late Upper Palaeolithic) age (ApSimon et al., 1961, p. 100) and are important craniometrically as some of few available which may represent a pre-Neolithic British physical type. Coll. ca. 1920 by Bristol Spelaeol. Soc; subm. by D. R. Brothwell from Bristol Univ. colln. Comment: date compares with stalagmite taken from inside Aveline's Hole skull, GrN-5393, $8110 \pm 150$ (unpub.) and Cheddar Man (Gough's Cave), BM-525, $9080 \pm 150,7130$ B.c. (below). Date will be important for eventual biometric reappraisal of British pre-Neolithic skulls. (See also Oakley and Campbell, in press.)

\section{BM-525. Gough's Cave}

$9080 \pm 150$

Collagen separated from tibia of human skeleton ("Cheddar Man") from Gough's Cave, Cheddar, Mendip, Somerset, England $\left(51^{\circ} 16^{\prime} \mathrm{N}\right.$ Lat, $2^{\circ} 45^{\prime} \mathrm{W}$ Long). Natl. Grid Ref. ST 467539. Burial was in cave earth passing laterally into breccia below Upper Stalagmite (Davies, 1904; Donovan, 1955). Coll. 1903 by R. C. Gough; subm. by K. P. Oakley. Comment (K.P.O.): date expected to be later than Cheddarian/Creswellian of Sun Hole (BM-524, 12,378 \pm 150, above) and agrees closely with human skeletons from similar archaeologic context in Aveline's Hole, BM-471, $9114 \pm 110,7164$ B.c. (above). (See also Oakley and Campbell, in press.)

\section{BM-542. Tormarton}

Collagen separated from part of tibia of human skeleton (Tormarton skeleton I, Ac. 113/1968) from W Littleton Down, Tormarton parish, Gloucestershire, England (51 $29^{\prime} 17^{\prime \prime} \mathrm{N}$ Lat, 20 $20^{\prime} 6^{\prime \prime} \mathrm{W}$ Long). Natl. Grid Ref. ST 767767. Two Middle Bronze age spear heads had penetrated skeleton, one still embedded in pelvis (Grinsell, 1968a, b; 1970). Coll. 1968 by C. Browne; subm. by L. V. Grinsell, City Mus., Bristol.

\section{BM-584. Sutton Hoo}

$1204 \pm 79$

Collagen separated from a human skull buried in grave pit at Sutton Hoo, Suffolk, England (52 $5^{\prime} \mathrm{N}$ Lat, $1^{\circ} 20^{\prime} \mathrm{E}$ Long). Natl. Grid Ref. TM 287487. Coll. 1969 and subm. by I. H. Longworth, British Mus. Comment (I.H.L.): skull was estimated to be from Early Iron age to Anglo-Saxon date. Radiocarbon measurement was made because bone from a prehistoric context at Sutton Hoo would help determine whether there was ever a body assoc. with Dark age Sutton Hoo ship-burial in Barrow I.

\section{Dendrochronology}

Wood (oak) from floor joists of Merton College Library, Oxford, England (51 $45^{\prime} \mathrm{N}$ Lat, $1^{\circ} 13^{\prime} \mathrm{W}$ Long) and from trusses over vault of nave of Norwich Cathedral, Norwich, Norfolk, England (52 $37^{\prime} \mathrm{N}$ Lat, $1^{\circ} 20^{\prime}$ E Long). Coll. 1968, 1969 and subm. by J. M. Fletcher, Univ. of Oxford. Samples form part of a master chart of annual widths and 
density variations of oak grown in certain regions of England (Fletcher and Hughes, 1970).

Timbers from other European medieval buildings, some subm. by J. M. Fletcher from $\mathrm{N}$ Berkshire and Oxford regions, were radiocarbondated (Fergusson and Libby, 1963, 1964; Berger, Fergusson, and Libby, 1965; Berger and Libby, 1966-1969). Interpretation of these dates was discussed by Berger and Libby (R., 1969, v. 11, p. 202-203) and by Fletcher (1968a, 1968b). Historical dates estimated from Stuiver-Suess curve (Stuiver and Suess, 1966) and a growth allowance is made for number of annual rings between point of sampling and bark, to establish likely date of use.

\section{Merton College Library}

Ring widths and densities were measured on several joists removed from library, built in A.D. 1377. Because floor was repaired ca. A.D. 1600, it was important to establish origin of beams.

\section{BM-526. Merton College Library}

$654 \pm 45$

Sample 116-I. Comment (J.M.F.): estimated date of use is ca. A.D. 1426, establishes that beam was part of original flooring of A.D. 1377.

\section{BM-527. Merton College Library}

$359 \pm 45$

Sample 116-II. Comment (J.M.F.): estimated historic dates are A.D. 1445 to A.D. 1655, as radiocarbon date corresponds to complex region of correction curve. Range suggests that beam formed part of repairs of ca. A.D. 1600. Measurement of a younger or older sample from same beam is desirable.

\section{Norwich Cathedral}

Records show that nave roof fell due to arson ca. A.D. 1270 and was replaced ca. A.D. 1275. There was re-roofing again ca. A.D. 1466 following another fire ca. A.D. 1463. Form of trusses from which samples were taken suggested 13th rather than 15th century date. Two samples were dated to help resolve this question and to aid selection of samples for dendrochronology from ca. 500 beams.

\section{BM-528. Norwich Cathedral}

Sample 125-IA. Estimated historic date: Ca. A.D. 1530.

$$
380 \pm 45
$$

$$
\text { A.D. } 1570
$$

\section{BM-529. Norwich Cathedral}

Sample 125-III. Estimated historic date: ca. A.D. 1507. Comment (J.M.F.): both historic dates are reasonably consistent (within ca. 50 yr) with a re-roofing following disaster of A.D. 1463.

\section{Faversham}

One charcoal and 2 bone samples from excavation of disused chapel at Stone, near Faversham, Kent, England (51 $1^{\circ} 19^{\prime} \mathrm{N}$ Lat, $0^{\circ} 52^{\prime} \mathrm{E}$ Long). 
Natl. Grid Ref. TQ 993613. Coll. 1968 and subm. by Sir Eric Fletcher and G. W. Meates. Site was originally Roman temple or mausoleum probably 4 th century A.D.), incorporated into Christian church in 7 th century and extended and rebuilt in Medieval period (Fletcher and Meats, 1970).

BM-479. Faversham

$$
1490 \pm 110
$$

Collagen separated from calvarium of juvenile human skull from a burial $1.6 \mathrm{~m}$ from $\mathrm{S}$ wall of chancel of ruined chapel at depth $8 \mathrm{~cm}$ below foundation raft.

\section{BM-480. Faversham}

$$
810 \pm 110
$$

Collagen separated from human pelvis from a burial immediately $\mathrm{E}$ of original $\mathrm{E}$ wall of chancel at depth $3.25 \mathrm{~m}$ below chancel floor.

\section{BM-481. Faversham}

$$
1400 \pm 110
$$

Charcoal (possibly from "wattle and daub") from within boundary of $S$ wall of chancel at depth $45 \mathrm{~cm}$ below Roman floor.

\section{Tel 'Erany series}

$$
\text { F. Israel }
$$

Eight samples of charred grain, charred olive stones, and charcoal from Tel 'Erany (formerly Tel Gath), E part of S Maritime plain between Askalon and Beth Guvrin (31 $40^{\prime} \mathrm{N}$ Lat, $34^{\circ} 50^{\prime} \mathrm{E}$ Long). Coll. 1957 (Area D) and 1961 (Area A, N) by Sh. Levi and Ephrath Yeivin, respectively; subm. by S. Yeivin, Dept. of Antiquities, Jerusalem, Israel (Yeivin, 1960a, 1961, 1967).

\section{BM-387. Tel 'Erany}

$4500 \pm 130$

Sample 1. Carbonized wheat from conflagration layer (No. 525, Loc. 2062, Stratum II, level 134.22 m, Area D). Expected date Early Canaanite II, ca. 2700 B.C.

\section{BM-388. Tel 'Erany}

$4340 \pm 130$

Sample 2. Carbonized wheat from conflagration layer (No. 505, Loc. 4702, Stratum IV, level $131.20 \mathrm{~m}$, Area D). Expected date, transition period from Chalcolithic to Early Canaanite II, ca. 3000 B.c.

BM-389. Tel 'Erany

Sample 3. Carbonized wheat from conflagration layer (No. 555, same context as Sample 2).

\section{BM-390. Tel 'Erany}

Sample 4. Charcoal from conflagration layer (No. 680, Loc. 2301, Stratum II3, level $133.55 \mathrm{~m}$, Area D). Expected date Early Canaanite II, ca. 2700 B.c. 
BM-391. Tel 'Erany

Sample 5. Carbonized olive stones from a large pottery vessel (No. 290, Loc. 4533, Stratum IV, level $131.67 \mathrm{~m}$, Area D). Expected date ca. 3000 B.c. (cf. Samples 2, 3).

\section{BM-392. Tel 'Erany}

$4470 \pm 140$

Sample 6b. Charcoal from under city wall, level 124.5 to $124.2 \mathrm{~m}$, Area N, L/10. Supposed to represent settlement conquered by Narmer (ca. 3000 to 3100 B.c.).

\section{BM-393. Tel 'Erany}

$4450 \pm 140$

Sample 7. Charred grain from level $125.05 \mathrm{~m}$, Area N, E/50, same context as Sample 6b, ca. 3000 to 3100 B.c.

\section{BM-394. Tel 'Erany}

Sample 8. Charcoal from oven, N sec. 145.05 to $144.55 \mathrm{~m}$, Area A. Expected date Middle Israelite layer, ca. 800 to 600 B.c.

General Comment: BM-387-393 appear too young by several hundred $\mathrm{yr}$ in agreement with evidence for $\mathrm{C}^{14}$ discrepancies. This is of particular interest because of the in situ discovery in one level of an ostracon of Narmer which provides tentative cross-check with Egyptian C14 chronology (Yeivin, 1960b, 1963, 1967, 1968). BM-394 agrees perfectly with archaeologic evidence that stratum belongs to later period of Middle Iron age.

$$
\text { G. Italy }
$$

\section{BM-496. Castenedolo skeleton}

$$
958 \pm 116
$$

Collagen separated from vertebrae and costae of human skeleton (ref. Castenedolo I) found at Castenedolo, Brescia, Italy $\left(45^{\circ} 28^{\prime} \mathrm{N}\right.$ Lat, $10^{\circ} 18^{\prime}$ E Long). Coll. 1880 by G. Ragazzoni; subm. by K. P. Oakley. Samples made available through Giuseppe Genna, Univ. of Rome. From one of several skeletons found in Pliocene marls at Castenedolo (Ragazzoni, 1880; Boule and Vallois, 1957) and originally interpreted as proof of great antiquity of Homo sapiens (Sergi, 1884). Comment (K.P.O.): comparison of nitrogen content of Castenedolo bones with range of nitrogen values of bones from Italian sites indicated that these skeletons were intrusive burials in Pliocene marls, but whether end-Pleistocene or Holocene (Recent), as seemed more probable, could only be settled by radiocarbon dating. (See also Oakley and Campbell, in press.)

\section{Soroki}

\section{H. Moldavian SSR}

Two wood charcoal samples (ref. Excavation 1, House 2, Quads. B1, B2) from excavation of a Tripolje culture settlement at Soroki, Moldavian SSR ( $48^{\circ} 08^{\prime} \mathrm{N}$ Lat, $28^{\circ} 12^{\prime} \mathrm{E}$ Long). Coll. 1967 by E. K. 
Černyš; subm. by R. Tringham, Univ. College, London. Samples date to transition of middle to late period $(B 2 / \mathrm{C})$ of Tripolje culture in USSR (Passek, 1961).

\section{BM-494. Soroki II}

$4792 \pm 116$

Sample 1, depth 1.5 to $1.6 \mathrm{~m}$ below surface.

2842 B.c.

\section{BM-495. Soroki II}

Sample 2, depth $2.2 \mathrm{~m}$ below surface. Comment (R.T.): 1st available dates for middle period of Tripolje culture in USSR; expected to be roughly contemporary with date for Valea Lupului, Rumania (Cucuteni B), GrN-1982, $3000 \pm 60$ B.C. (Vogel and Waterbolk, 1963). Dates fit well with estimated beginning of Late Tripolje culture in E Europe (Gimbutas, 1965).

\section{Sweden}

\section{BM-410. Kvarnby}

$4850 \pm 115$ 2900 B.C.

Protein fraction from antler from a flint mine at Kvarnby, Husie parish, near Malmo, Scania, Sweden (55 $36^{\prime} \mathrm{N}$ Lat, $12^{\circ} 58^{\prime} \mathrm{E}$ Long), where erratic large chalk blocks containing flint occur. Coll. ca. 1900; subm. by G. de G. Sieveking, British Mus., from colln. of Natl. Mus., Stockholm, for comparison with dates from flint mines in S England. Comment: though generally regarded as Neolithic, it has been claimed that sites were not flint mines and were probably not in use earlier than Roman Iron age (Althin, 1951, 1955). This view is not confirmed by date, which agrees well with dates obtained for Neolithic flint mines in $\mathbf{S}$ England (Barker, Burleigh, and Meeks, 1969a; Sieveking, ms. in preparation).

\section{REFERENCES}

Althin, C. A., 1951, The Scanian flint mines: Meddelanden Från Lunds Univ. Historiska Mus., 1950-1951, p. 139-158. 1955, The picks of the Scanian "flint mines": Från Lunds Univ. Historiska Mus. Medd., 1954-1955, p. 224-227.

ApSimon, A. M., Donovan, D. T., and Taylor, H., 1961, The stratigraphy and archaeology of the late-glacial and post-glacial deposits at Brean Down, Somerset: Univ. Bristol Spelaeol. Soc. Proc., v. 9, p. 100-102.

Arnold, D. and Settgast, J., 1965, Erster vorbericht über die vom Deutschen Archäologischen Institut im Asasif unternommenen Arbeiten: Deutsch. Archäol. Inst. Abt. Kairo Mitt., v. 20, p. 47-61.

Ashbee, P., 1964, The radiocarbon dating of Fussell's Lodge long barrow: Antiquity, v. 38 , p. $139-140$. v. 100 , p. $1-806$, The $\mathbf{F}$.

Atkinson, R. J, 1965, Wayland's Smithy: Antiquity, v. 39, p. 126-133.

Barker, Harold, Burleigh, Richard, and Meeks, Nigel, 1969a, British Museum natural radiocarbon measurements VI: Radiocarbon, v. 11, p. 278-294.

- 1969b, New method for the combustion of samples for radiocarbon dating: Nature, v. 221 , p. $49-50$

Barker, Harold and Mackey, C. J., 1959, British Museum natural radiocarbon measurements I: Am. Jour. Sci. Radiocarbon Supp., v. 1, p. 81-86. carbon, v. 3, p. 39-45. 
1963, British Museum natural radiocarbon measurements IV: Radiocarbon, v. 5, p. 104-108.

Becker, C. J., 1951, Maglemosekultur på Bornholm: Aarbøger for Nord. Oldkyndighed og Hist., p. 96-177 (English summary, p. 171-177)

Bemrose, G. J. V., 1953-54, Trans. N Staffs. Field Club, Stafford, v. 88, p. 104.

Berger, Rainer, 1970, Ancient Egyptian radiocarbon chronology: Royal Soc. (London) Philos. Trans. A., v. 269, p. 23-36.

Berger, Rainer, Fergusson, G. I., and Libby, W. F., 1965, UCLA radiocarbon dates IV: Radiocarbon, v. 7, p. 336-371.

Berger, Rainer and Libby, W. F., 1966, UCLA radiocarbon dates V: Radiocarbon, v. 8 , p. $467-497$

1967, UCLA radiocarbon dates VI: Radiocarbon, v. 9, p. 477-504.

1968a, UCLA radiocarbon dates VII: Radiocarbon, v. 10, p. 149-160.

1968b, UCLA radiocarbon dates VIII: Radiocarbon, v. 10, p. 402-416.

1969, UCLA radiocarbon dates IX: Radiocarbon, v. 11, p. 194-209.

Boule, M. and Vallois, H. V., 1957, Fossil Men: London, Thames and Hudson, p. 107

Bruce-Mitford, R. L. S., 1967, A new wooden ship's figure-head found in the Scheld at Moerzeke-Mariekerke: Acta Archacologica, v. 38, p. 199-209. 1970, Ship's figure-heads in the Migration period and Early Middle ages: Antiquity, v. 44, p. 146-148.

Buxton, D. R., 1946, Ethiopian rock-hewn churches: Antiquity, v. 20, p. 60-69. 92, p. 192. The Christian antiquities of Northern Ethiopia: Archaeologia, v.

Calder, C. S. T., 1958, Report on the discovery of numerous stone age house-sites in Shetland: Soc. Antiquaries of Scotland Proc. 1955-56, v. 89, p. 340-397.

Callow, W. J., Baker, M. J., and Hassall, G. I., 1965, National Physical Laboratory radiocarbon measurements III: Radiocarbon, v. 7, p. 156-161.

Case, H., 1956, The Neolithic causewayed camp at Abingdon, Berks.: Antiquaries Jour., v. 36, p. 11-30

Caton-Thompson, G. and Gardner, E. W., 1934, The Desert Fayum, v. I-II: London, Royal Anthropol. Inst., p. 45-46, pl. XXIX(2).

Cheney, H. J., 1935, An eneolithic occupation site at Playden near Rye: Antiquaries Jour., v. 15 , p. 152-164.

Churchill, D. M., 1962, The stratigraphy of the Mesolithic Sites III and V at Thatcham, Berkshire, England: Prehist. Soc. Proc., v. 28, p. 362-370.

Coles, J. M. and Hibbert, F. A., 1968, Prehistoric roads and tracks in Somerset, England: 1, Neolithic: Prehist. Soc. Proc., v. 34, p. 238-258.

Coles, J. M., Hibbert, F. A., and Clements, C. F., 1970, Prehistoric roads and tracks in Somerset, England: 2, Neolithic: Prehist. Soc. Proc., v. 36, p. 125-151.

Connah, Graham, 1965, Excavations at Knap Hill, Alton Priors, 1961: Wiltshire Archaeol. and Nat. Hist. Mag., v. 60, p. 1-23. 1969a, Radiocarbon dating for Knap Hill: Antiquity, v. 43, p. 304-305. 1969b, Radiocarbon dating and laboratory examinations for Knap Hill: Wilshire Archaeol. and Nat. Hist. Mag., v. 64, p. 113-114.

Crawford, O. G. S., 1929, Durrington Walls: Antiquity, v. 3, p. 49-59.

Davies, H. N., 1904, The discovery of human remains under the stalagmite-floor of Gough's Cavern, Cheddar: Geol. Soc. Quart. Jour., v. 60, p. 335-348.

Dewar, H. S. L. and Godwin, H., 1963, Archaeological discoveries in the raised bogs of the Somerset levels, England: Prehist. Soc. Proc., v. 29, p. 17-49.

Donovan, D. T., 1955, A Pleistocene deposit at Gough's Cave, Cheddar, including an account of recent excavations: Univ. Bristol Spelaeol. Soc. Proc., v. 7, p. 91.

Duell, P., 1938, The Mastaba of Mereruka, pt. I: Chicago, Univ. of Chicago Oriental Inst. pubs., v. 31, p. 5-7.

Edwards, I. E. S., 1970, Absolute dating from Egyptian records and comparison with carbon-14 dating: Royal Soc., (London) Philos. Trans. A., v. 269, p. 11-18.

Emery, W. B., 1938, The Tomb of Hemaka: Excavations at Sakkara, 1938: Cairo, Govt. Press, p. 1-64. p. $5-38$. 1954, Great Tombs of the First Dynasty II: London, Egypt Explor. Soc.,

Evans, J. G. and Burleigh, R., 1969, Dates for the South Street long barrow, Wiltshire: Antiquity, v. 43 , p. $144-145$.

Evans, J. G. and Smith, I. F., 1967, Cherhill, Oliver's Hill Field (Neol. Wilts.): Univ. Bristol (Extra Mural Dept.), C. B. A. Archaeol. Rev., Gp. XII and XIII, no. 2, p. 8-9. 
Fakhry, A., 1959, The Monuments of Sneferu at Dahshur, v. 1, The Bent Pyramid: Cairo, Govt. Printing Offices, p. 1-123, pl. I-LI.

Fisher, C. S., 1924, A group of Theban tombs: Univ. of Pennsylvania Mus. Jour., v. 15 , p. $28-49$.

Fergusson, G. J. and Libby, W. F., 1963, UCLA radiocarbon dates II: Radiocarbon, v. 5 , p. 1-22.

1964, UCLA radiocarbon dates III: Radiocarbon, v. 6, p. 318-339.

Fletcher, E. and Meates, G. W., 1970, The ruined church of Stone-by-Faversham: Antiquaries Jour., v. 49, p. 273-294.

Fletcher, John, 1968a, Radiocarbon dating for Medieval timber buildings: Antiquity, v. 42 , p. $230-231$.

p. 1968b, Crucks in the West Berkshire and Oxford region: Oxoniensia, v. 33,

Fletcher, J. M. and Hughes, J. F., 1970, Uses of X-rays for density determinations and dendrochronology: Univ. of British Columbia Conf., Vancouver, 19-20 Feb., 1970: Vancouver, Fac. of Forestry Bull. no. 7, p. 41-54.

Fowler, P. J. and Evans, J. G., 1967, Plough-marks, lynchets and early fields: Antiquity, v. 41 , p. $289-301$.

Froom, F. R., 1963, The Mesolithic around Hungerford: Newbury Dist. Field Club Trans., v. 11, no. 2, p. 62-87.

1964 An axe of Dorset chert from a Mesolithic site at Kintbury: Berkshire Archaeol. Jour., v. 61, 1963-1964, p. 1-3.

Gilot, E., Ancion, N., and Capron, P. C., 1966, Louvain natural radiocarbon measurements IV: Radiocarbon, v. 8, p. 248-255.

Gimbutas, M., 1965, The relative chronology of Neolithic and Chalcolithic cultures in Eastern Europe, in: Ehrich, R. W., Chronologies in Old World Archaeology: Chicago and London, Univ. of Chicago Press, p. 459-502.

Godfray, A. D. and Burdo, C., 1949, Excavations at the Pinnacle, parish of St. Ouen, Jersey (1930-1936): Soc. Jersiaise Bull., v. 15, no. 1, p. 21-100.

Godwin, Harry, 1960, Prehistoric wooden trackways of the Somerset levels; their construction, age and relation to climatic change: Prehist. Soc. Proc., v. 26, p. 1-36. construction, age and relation to climatic change: Prehist. Soc. Proc., v. 26, P. 1-36. ham and Frogholt: Festschrift Franz Firbas, Veröff. Geobot. Inst. Zurich, v. 37, p. 83-99.

Godwin, Harry and Switsur, V. R., 1966, Cambridge University national radiocarbon measurements VIII: Radiocarbon, v. 8, p. 390-400.

Godwin, Harry, Walker, Donald, and Willis, E. H., 1957, Radiocarbon dating and postglacial vegetational history. Scaleby Moss: Royal Soc. (London) Proc., Ser. B,

v. 147, p. 352-366.
Godwin, Harry and Willis, E. H., 1962, Cambridge University natural radiocarbon measurements V: Radiocarbon, v. 4, p. 57-70.

1964, Cambridge University natural radiocarbon measurements VI: Radiocarbon, v. 6, p. 116-137.

Greig, C., 1970, Excavations at Castle Point, Troup, Banffshire: Aberdeen Univ. Rev., v. 43,3 , no. 143 , p. $274-283$.

Grinsell, L. V., 1968a, City Museum, Bristol, recent archaeological accessions: Bristol Archaeol. Res. Group Bull., v. 3, no. 3, Dec. 1968, p. 64. 1968b, Tormarton, West Littleton Down: C. B. A. Archaeol. Rev., Gp. XII and XIII, no. 3, p. 8.

1970, Prehistoric skeletons from Tormarton, Gloucestershire: evidence of a Bronze age murder or skirmish: Bristol City Mus., Inf. Sheet no. A7.70.

Hawkes, J., 1937, The archaeology of the Channel Islands II; the Bailiwick of Jersey: Jersey, Soc. Jersiaise, p. 164.

Henshall, Audrey S. and Wallace, J. C., 1965, The excavation of a chambered cairn at Embo, Sutherland: Soc. Antiquaries of Scotland Proc. 1962-63, v. 96, p. 9-36.

Hess von Wichdorff, H., 1931, in: Die Thüringer Hohlen, v. 2, p. 8-22.

Jackson, J. W., 1956, The Caerwys tufa: Liverpool and Manchester Geol. Jour., v. 1, pt. 4, p. xxiv-xxviii.

Kerney, M. P., Brown, E. M., and Chandler, T. J., 1964, The late-glacial and postglacial history of the chalk escarpment near Brook, Kent: Royal Soc. (London) Philos. Trans. B., v. 248, p. 135-204.

Leclant, J., 1961, Montouémhat Quatrième prophète d'Amon: Cairo, Inst. Francais d'Archaéol. Orientale, Bib. d'etude, v. 35, pls. LVI, LVII. 
1966, Récentes recherches à la pyramide de Téti à Saqqarah: Soc. Francaise d'Egyptologie Bull., no. 46, p. 9-16.

Leeds, E. T., 1927, A Neolithic site at Abingdon, Berkshire: Antiquaries Jour., v. 7, p. $438-464$. p. $461-477$.

Libby, W. F., 1952, Radiocarbon dating, Chicago, Univ. of Chicago Press, p. 70-71.

Matthews, D. H., 1949, The restoration of the monastery church of Debra Damo, Ethiopia: Antiquity, v. 23, p. 180-187.

Matthews, D. H. and Mordini, A., 1959, The monastery of Debra Damo, Ethiopia: Archaeologia, v. 97, p. 1-59.

McBurney, C. B. M., 1960, Two soundings in Badger Hole: Mendip Nature Res. Comm., v. 50-51, p. 19-27.

Mellars, P. A., 1969, Radiocarbon dates for a new Creswellian site: Antiquity, v. 43, p. $308-310$.

Mercer, J., 1969, Stone tools from a washing-limit of the highest postglacial transgression, Lealt Bay, Isle of Jura: Soc. Antiquaries of Scotland Proc., 1967-68, v. 100 , p. $1-46$.

1970, Soc. Antiquaries of Scotland Proc., 1969-70, v. 101, in press

Money, J. H., 1966, Iron working site at Withyham: Kent Archaeol. Res. Gps. Council Newsletter, no. 4, May 1966, p. 12-14.

1967, Minepit Wood, Withyham, Sussex: Hist. Metallurgy Gp. Bull., pt. 8, Jan. 1967, p. 45.

1968, Iron working site at Withyham, Sussex: Kent Archaeol. Rev., no. 11, Feb. 1968, p. 5-7.

1971, Medieval Archaeology, in press.

Mortillet, G. de (ed.), 1868, Silex taillés de Spienne: Materieux pour l'histoire primitif et naturelle de l'homme, v. 4, p. 119-121.

Nims, C. F., 1965, Thebes of the Pharaohs: London, Elek Books, p. 76

Nour, M. Z., Iskander, Z., Osman, M. S., and Moustafa, A. Y., 1960, The Cheops Boats, pt. 1: Cairo, Govt. Printing Offices, pl. XII.

Oakley, K. P. and Campbell, B. G. (eds.), Catalogue of fossil Hominids, pt. 2: Europe: British Mus. (Nat. Hist.), London, in press.

Palmer, Susann, 1969, Third interim report on the excavation of a Mesolithic site at Portland Bill: Dorset Nat. Hist. and Archaeol. Soc. Proc., v. 90, p. 163. 1970, The stone age industries of the Isle of Portland, Dorset, and the utilisation of Portland chert as artifact material in Southern England: Prehist. Soc. Proc., v. 36, p. 82-115.

Passek, T. S., 1961, Early agricultural Tripolje tribes of the Dneister basin (in Russian): Materialy i Issledovaniya po Arkheologii SSSR (MIA): Akad. Nauk SSSR, Moscow, no. 84, p. 1-224.

Petrie, W. M. F., 1909, Qurneh: London, Bernard Quaritch, p. 6, pl. VIII (plan).

Quibell, J. E., 1898, The Ramasseum: London, Bernard Quaritch, pl. I (top, chamber 1).

Ragazzoni, G., 1880, La collina di Castenedolo: Commentari di Ateneo di Brescia, 1880 , p. $120-128$.

Ralph, E. K., 1959, University of Pennsylvania radiocarbon dates III: Am. Jour. Sci. Radiocarbon Supp., v. 1, p. 45-58.

Schlotheim, E. F. von, 1820, Die Petrefactenkunde: Gotha, p. 1-4, 8-9.

Seele, K., 1959, The tomb of Tjanefer at Thebes: Chicago, Univ. of Chicago Oriental Inst. pubs., v. 86 , pls. $1 \mathrm{~A}, 1 \mathrm{~B}$.

Sergi, G., 1884, L'Uomo terziario in Lombardia: Archo. Antrop. Etnol., v. 14, p. 303-318.

Seton-Williams, M. V., 1965, Tell el Fara'in Expedition 1964-65: Jour. Egyptian Archaeol., v. 51, p. 9-15.

1966, Tell el Fara'in Expedition 1966: Jour. Egyptian Archaeol., v. 52, p. $163-171$. p. 5 -22.

Smith, I. F. and Evans, J. G., 1968, Excavation of two long barrows in North Wiltshire: Antiquity, v. 42, p. 138-142.

Stone, J. F. S., Piggott, S., and Booth, A. St. J., 1954, Durrington Walls, Wiltshire; recent excavations at a ceremonial site of the early second millennium B.C.: Antiquaries Jour., v. 34, p. 155-177. 
Straker, E., 1931, Wealden Iron: London, Bell and Sons, p. 27, 257.

Stuiver, Minze and Suess, H. E., 1966, On the relationship between radiocarbon dates and true sample ages: Radiocarbon, v. 8, p. 534-540.

Suess, H. E., 1967, Bristlecone pine calibration of the radiocarbon time scale from 4100 B.C. to 1500 B.C. (SM-87/52): Monaco Symposium, Monaco, 2-10 Mar., 1967: Vienna, I.A.E.A., p. 143-151.

Täckholm, V. and Drar, M., 1941, Flora of Egypt, v. I: Cairo, Fouad I Univ., p. 42-79.

Tauber, Henrik, 1960, Copenhagen radiocarbon dates IV: Am. Jour. Sci. Radiocarbon Supp., v. 2, p. 12-25.

Tratman, E. K., 1955, Second report on the excavations at Sun Hole, Cheddar-the Pleistocene levels: Univ. Bristol Spelaeol. Soc. Proc., v. 7, p. 61-75, figs. 7, 8, 10

Vatcher, F. de M., 1959, The radiocarbon dating of the Nutbane long barrow: Antiquity, v. 33, p. 289.

1961, The excavation of the long mortuary enclosure on Normanton Down, Wilts: Prehist. Soc. Proc., v. 27, p. 160-173.

Vogel, J. C. and Waterbolk, H. T., 1963, Groningen radiocarbon dates IV: Radiocarbon, v. 5, p. 163-202.

Vries, H. de and Waterbolk, H. T., 1958, Groningen radiocarbon dates III: Science, v. 128 , p. $1550-1556$.

Wainwright, G. J., 1963, A reinterpretation of the microlithic industries of Wales: Prehist. Soc. Proc., v. 29, p. 99-132.

1967, The excavation of the henge monument at Durrington Walls, Wiltshire, 1966: Antiquaries Jour., v. 47, p. 166-184.

1968, Durrington Walls a ceremonial enclosure of the 2nd millennium B.C.: Antiquity, v. 42 , p. $20-26$.

Wainwright, G. J., et al., 1971, Durrington Walls: Soc. Antiquaries (London), Res. Rept., in press.

Wainwright, G. J. and Longworth, I. H., 1970, The excavation of a group of round barrows on Ampleforth Moor, Yorkshire: Yorkshire Archaeol. Jour., v. 42, pt. 167,1968 , p. 283-284.

Wheeler, R. E. M., 1943, Maiden Castle, Dorset: Soc. Antiquaries (London), Rept. Res. Comm., no. XII, p. 344-346.

White, G. F., 1970, Excavation of the Dead Man's Cave, North Anston: Worksop Pub. Libr. and Mus., p. 1-6, figs. 1-4.

Wymer, J., 1962, Excavations at the Maglemosian sites at Thatcham, Berkshire, England: Prehist. Soc. Proc., v. 28, p. 329-361.

Yeivin, S., 1960a, A decade of archaeology in Israel, 1948-1958: Istanbul, Dutch Hist. Archaeol. Inst., p. 4, fig. 1.

1960b, Early contacts between Canaan and Egypt: Israel Explor. Jour., v. 10, p. 193-203.

1961, First preliminary report on the excavations at Tel "Gat" (seasons 1956-1958): Jerusalem, English pt., p. 1-20.

1963, Further evidence of Narmer at "Gat": Or. Ant., v. 2, p. 205-213.

1967, A new Chalcolithic culture at Tel 'Erany and its implications for early Egypto-Canaanite relations: Jerusalem, Fourth World Cong. of Jewish Studies, Jerusalem, 1967, p. 45-48.

1968, Additional notes on the early relations between Canaan and Egypt: Jour. Near Eastern Studies, v. 27, p. 37-50. 